\title{
PjBL dengan Penugasan Video Tutorial di Masa Pandemi COVID-19: Peningkatan Ketertarikan Belajar serta Penguatan Kreatifitas dan Kepercayaan Diri
}

\author{
Nugroho Wibowo 1 \\ ${ }^{1}$ SMK N 1 Saptosari \\ Email: asyifahaifa3@gmail.com
}

\begin{abstract}
One of the results of evaluating learning activities during the COVID-19 pandemic shows that students feel bored. On the other hand, current learning does not have to pursue curriculum targets. Teachers need to do character strengthening. Creativity and confidence need to be strengthened in Creative Products and Entrepreneurship (PKK) subjects. This article describes the implementation of Project-Based Learning (PjBL) with video tutorials to make students interested and strengthen their creative and self-confident character. The research method used is quasi-experimental, which is described from the researchers' best practices. The PjBL stages with video tutorial assignments consist of: (1) information and task regulations; (2) exploring ideas; (3) video making; and (4) networking and rewarding. The results of the evaluation of the learning implementation are: (1) $83.33 \%$ of students tend to be interested in video tutorial assignments; and (2) $80.56 \%$ of students who experienced a strengthening of creativity and $91.67 \%$ of students who experienced a strengthening of selfconfidence. The success of this learning is supported by the enthusiasm and cooperative nature of students. On the other hand, the obstacles to learning activities are poor signal, video quality, and limited internet quota. This article shows teachers' best experiences in implementing PjBL by assigning video tutorials to increase interest in learning while strengthening creativity and self-confidence.
\end{abstract}

Keywords: PjBL, video tutorial, interested, creativity, confidence

\begin{abstract}
ABSTRAK
Salah satu hasil evaluasi kegiatan belajar di masa pandemi COVID-19 menunjukkan bahwa peserta didik merasa bosan. Dilain pihak, pembelajaran saat ini tidak harus mengejar target kurikulum. Guru perlu melakukan penguatan karakter. Kreatifitas dan kepercayaan diri perlu dikuatkan pada mata pelajaran Produk Kreatif dan Kewirausahaan (PKK). Artikel ini mendeskripsikan penerapan Project-Based Learning (PjBL) dengan penugasan video tutorial untuk membuat peserta didik tertarik serta menguatkan karakter kreatif dan percaya diri. Metode penelitian yang digunakan adalah kuasi eksperimen yang dideskripsikan dari hasil pengalaman terbaik (best practice) peneliti. Tahapan PjBL dengan penugasan video tutorial terdiri atas: (1) informasi dan regulasi tugas; (2) penggalian ide; (3) pembuatan video; dan (4) pencarian jejaring dan pemberian reward. Hasil evaluasi pelaksanaan pembelajaran tersebut adalah: (1) $83.33 \%$ peserta didik cenderung tertarik pada penugasan video tutorial; serta (2) $80.56 \%$ peserta didik yang mengalami penguatan kreatifitas dan $91.67 \%$ peserta didik yang mengalami penguatan percaya diri. Keberhasilan pembelajaran ini didukung oleh semangat dan sifat kooperatif peserta didik. Dilain pihak, penghambat kegiatan belajar tersebut adalah sinyal yang kurang baik, kualitas video dan kuota internet yang terbatas. Artikel ini berkontribusi untuk memperlihatkan pengalaman terbaik guru pada penerapan PjBL dengan penugasan video tutorial untuk meningkatkan ketertarikan belajar sekaligus menguatkan kreatifitas dan kepercayaan diri.
\end{abstract}

Kata kunci: PjBL, video tutorial, ketertarikan belajar, kreatifitas, kepercayaan diri

\section{PENDAHULUAN}

2 Maret 2020 merupakan pertama kali kasus Coronavirus Disease (COVID-19) terdeteksi di Indonesia [1]. Penyakit tersebut menginfeksi paru-paru akibat virus Severe Acute Respiratory Syndrome Coronavirus-2 (SARS-CoV-2). Lebih lanjut, status pandemi global dikeluarkan WHO di tanggal 11 Maret 2020 [2]. Status tersebut merupakan efek dari kecepatan penyebaran yang tinggi hingga seluruh dunia dan keparahan yang ditimbulkan hingga kematian. Salah satu upaya menahan penyebaran pandemi tersebut adalah meliburkan kegiatan belajar mengajar sementara atau menutup Institusi Pendidikan [3], [4]. Lebih lanjut, pemerintah Indonesia mengambil kebijakan untuk melakukan pembelajaran jarak jauh dengan belajar dari rumah, sebagai pengganti pembelajaran secara langsung berupa tatap muka di kelas [5]-[7]. Alternatif pembelajaran tersebut dilakukan untuk 
mengantisipasi penularan virus melalui kontak langsung antar manusia.

Terdapat beberapa permasalahan pada pelaksanaan kegiatan belajar dari rumah yang menghambat jalannya kegiatan pembelajaran. Kegiatan belajar jarak jauh di waktu pandemi menimbulkan kejenuhan peserta didik [8]. Rasa bosan dan jenuh ketika belajar di rumah menurunkan semangat belajar [9]. Salah satu temuan hasil observasi peneliti adalah munculnya kebosanan peserta didik akibat: (1) pembelajaran masih bersifat satu arah (teacher oriented), sehingga peserta didik menjadi kurang aktif; dan (2) tugas yang diberikan guru kurang bervariasi. Guru harus berupaya menghadirkan kegiatan belajar dari rumah yang dapat menghindari rasaa bosan peserta didik. Kendala pada pembelajaran jarak jauh lain selama pandemi adalah kesiapan ekonomi peserta didik dan kurangnya interaksi sosial antara pengajar dengan peserta didik [10]. Hal tersebut selaras dengan hasil observasi peneliti lainnya, yaitu terkait sarana prasarana yang tidak sama antar peserta didik, yaitu spesifikasi telepon seluler, jaringan internet, dan kuota internet yang terbatas di lingkungan keluarga tingkat menengah kebawah.

Pelaksanaan kegiatan belajar dari rumah tidak membebani peserta didik, guru dan orangtua. Kegiatan belajar dari rumah diharapkan mudah dipahami dan memiliki kemenarikan bagi peserta didik. Beberapa teknologi digunakan untuk mendukung hal tersebut adalah penggunaan WhatsApp (WA) dan Google Classroom (GC) sebagai aplikasi yang dimanfaatkan pada aktivitas belajar dari rumah [11]. Hal tersebut sejalan dengan hasil observasi pada kelas XI TKR A SMK Negeri 1 Saptosari oleh peneliti pada dua kali kegiatan belajar dari rumah adalah: (1) teknologi yang digunakan untuk berkomunikasi antara peserta didik dengan guru adalah aplikasi Short Massage Service (SMS), WA, GC; (2) tugas yang diberikan guru kurang lebih $90 \%$ bersifat menjawab pertanyaan (pilihan ganda dan uraian singkat); dan (3) guru mengirimkan materi ke peserta didik melalui internet.
Usia 16 sampai 18 tahun atau usia anak SMA/SMK/MA termasuk dalam kategori tahap remaja akhir dalam tahapan perkembangan seorang peserta didik. Pada tahapan tersebut, ranah afektif yang terdiri atas watak perilaku seperti nilai, emosi, sikap, minat, atau perasaan masih labil. Para peserta didik harus diberikan peluang dalam menentukan pengambilan keputusan terkait penyelesaian sebuah permasalahan karena hal tersebut akan membantu para peserta didik dalam proses perkembangannya. Pada waktu tersebut, seseorang dihadapkan dengan penemuan beberapa hal, yaitu mengenai siapa mereka, bagaimana kedepan, dan kemana tujuan kehidupanya, anak remaja dihadapkan dengan status orang dewasa dan banyak peran baru [12].

Salah satu mata pelajaran di SMK adalah Produk Kreatif dan Kewirausahaan (PKK). PKK merupakan mata pelajaran yang ditempuh pada kompetensi keahlian di SMK di bidang keahlian Teknologi dan Rekayasa. Peneliti adalah guru SMK program keahlian Teknik Otomotif. Dalam rangka mengatasi kejenuhan peserta didik di masa pandemi COVID-19 terkait pembelajaran jarak jauh dan untuk mengapresiasi kebutuhan eksistensi diri seorang remaja SMK tersebut, maka peneliti mempunyai pemikiran untuk memberikan penugasan pembuatan video tutorial dengan tema pekerjaan-pekerjaan di dunia otomotif. Tema tersebut diambil dengan alasan peserta didik cenderung akan menyukai materi yang berkaitan dengan program keahlianya, disamping itu dengan pembuatan video tutorial peserta didik dapat mengekspresikan kemampuan praktik dalam pekerjaan otomotif.

Pemberian pelaksanaan kegiatan belajar yang terbaik merupakan kewajiban guru sebagai pemeran utama terkait pemenuhan pendidikan. Hal tersebut dapat mendorong keberhasilan peserta didik menjadi profesional di bidangnya.

Pencapaian tujuan belajar tersebut menuntut guru untuk mampu melakukan perancangan dan penerapan pembelajaran. Perencanaan kegiatan belajar dari rumah disesuaikan dengan capaian tujuan 
pembelajaran. Aktivitas belajar terdiri atas tiga kegiatan belajar, diantaranya awal, inti dan akhir. Pembentukan kompetensi peserta didik dalam mencapai tujuan pembelajaran diimplementasikan melalui ketiga kegiatan pembelajaran tersebut secara menyeluruh dan berurutan.. Lebih dalam, kegiatan belajar dari rumah oleh guru perlu diupayakan tidak menimbulkan kejenuhan bagi peserta didik. Ketuntasan untuk semua materi dalam kurikulum pada masa pandemi ini tidak menjadi patokan. Hal tersebut merupakan arahan dari Mendikbud. Guru tidak hanya mengejar target kurikulum saja, melainkan juga harus membekali peserta didik dengan nilai-nilai penguatan karakter [13]. Beberapa karakter yang dibutuhkan peserta didik di era Revolusi Industri 4.0 adalah kreatif dan percaya diri [14].

Kreativitas dalam belajar dapat menjadi penentu keberhasilan peserta didik. Salah satunya adalah melalui kreativitas manusia dalam membentuk teori, konsep, teknologi dan keadaan terdesak seperti masa pandemi ini dalam bentuk inovasi ilmu pengetahuan. Kesulitan saat mendapatkan permasalahan dapat diminimalisir apabila kemampuan kreatif dimiliki oleh peserta didik [15]. Kreatifitas tidak berasal dari faktor genetik, kreatifitas dapat terbentuk dari keadaan yang ada disekitar manusia tersebut lingkungan memiliki peran yang jauh lebih besar dibandingkan dengan faktor keturunan. Terdapat manusia-manusia yang terlahir memiliki kreatifitas, sedangkan beberapa tidak kreatif. Akan tetapi, setiap individu dapat menjadi kreatif dengan dukungan berbagai pihak disekitarnya. Melalui pembentukan dan pelatihan secara berkala, setiap individi dapat mengembangkan aspek kreatifitas. Divergensi kemampuan berpikir untuk mempu menelaah variasi atau alternatif penyelesaian dari suatu permasalahan adalah bentuk dari kreatifitas [16]. Pendapat tersebut dapat disebut dengan kognitif aspek Guilfort dengan berpikir divergen. Kemampuan berpikir secara menyebar merupakan arti dari konsep berpikir divergen. Orang dengan kemampuan berpikir secara divergen memiliki perbedaan mengenai cara pandang terhadap stimulus. Suatu stimulus dipandang dari sudut pandang yang bervariatif oleh orang yang berpikir divergen. Penelaahan suatu objek memiliki fungsi yang bervariatif diluar fungsi utamanya merupakan ciri dari individu yang memiliki kreativitas. Guilford memiliki pemaknaan kreativitas tersebut. Konsep kreativitas tersebut ditanamkan kepada orang lain dari tahun ke tahun.

Sesuai dengan tingkatan umur pada manusia, manusia dapat berkembang sesuai dengan tingkat kedewasaanya. Salah satu potensi yang terdapat pada peserta didik adalah perkembangan kemampuan kreatif. Keterbatasan wawasan dan tidak dikembangkannya kemampuan berpikir merupakan hal yang menyebabkan potensi memiliki kreatifitas seorang peserta didik tidak muncul. Pengembangan potensi individu kreatif yang terencana dan sistematis perlu dilakukan agar kreatifitas peserta didik dapat digunakan untuk hal yang bermanfaat dan tepat secara optimal [16]. Upaya pengembangan kreatifitas peserta didik pada pembelajaran yang dapat dilakukan guru diantaranya adalah dengan membuat ikatan yang kuat dalam kelas yang diajarkanya, guru sebaiknya mengetahui secara mendalam apa yang sedang terjadi pada peserta didiknya salah satu caranya dengan mengeksploitasi momen-momen penting dalam kehidupanya semisal membuat kejutan pada hari ulang tahun peserta didik, momen juara pada suatu perlombaan dan lain sebagainya [17].

Berpijak dari beberapa pemaparan kajian, dapat dinyatakan bahwa kreativitas adalah cara berpikir secara divergen dan kemampuan menganalisis dari berbagai sudut pandang dalam mengatasi atau menyelesaikan suatu masalah. Kreatifitas berkembang dalam bentuk yang berbeda tergantung lingkungan dan keadaan dia berada. Setiap lingkungan kerja terdapat perbedaan permasalahan dan situasi yang berbeda, oleh karena itu kreatifitas tidak banyak dipengaruhi oleh faktor genetik.

Salah satu sikap penting yang harus dimiliki peserta didik sebagai modal dasar untuk sukses diberbagai bidang adalah percaya diri. Percaya 
diri (self confidient) merupakan perasaan mampu untuk mendapatkan pencapaian berbagai tujuan hidup dikarenakan memiliki keyakinan diri terhadap aspek-aspek kelebihan yang dimiliki [18]. Seseorang yang percaya diri akan merasa memiliki kemampuan dalam penyelesaian suatu permaslahan atau pekerjaan dan memiliki keberanian dalam pengambilan keputusan. Lebih lanjut dijelaskan secara sederhana bahwa percaya diri dapat diartikan sebagai suatu keyakikan seseorang pada aspek-aspek kelebihan yang dimiliki, dimana melaui keyakinan tersebut, seseorang terbantu untuk merasa mampu melakukan berbagai pencapaian tujuan hidup. Penumbuhan kepercayaan diri peserta didik melalui pendidikan di sekolah memiliki peran yang penting. Kegiatan sosialisasi dapat ditemukan di lingkungan sekolah. Guru sebagai role model bagi peserta didik melalui pembawaan yang ramah dan hangat memiliki peran dalam pembentukan percaya diri peserta didik. Lebih lanjut, pengungkapam pendapat didepan umum secara berani merupakan langkah unjuk diri yang dapat dilakukan peserta diri untuk memupuk percaya diri [19].

Rendahnya tingkat percaya diri pada peserta didik akan berpengaruh terhadap prestasi belajarnya, menurut Stankov, Morony \& Lee dalam [20] dampak yang ditimbulkan dari rendahnya percaya diri adalah menurunnya performa akademik, motivasi dan performa akademik. Terdapat faktor internal dan eksternal yang membentuk kepercayaan diri [21]. Contoh dari factor internal diantarnya adalah terkait pandangan pribadi secara mental mental (self concept), keyakinan seseorang (self efficacy), kemampuan mengerjakan sesuatu secara mandiri, kesadaran akan harga diri seseorang (self esteem), dan tekad kuat seseorang mengenai keberhasilan mencapai cita-cita. Berbeda dari hal tersebut, Pendidikan baik formal maupun non-formal serta lingkungan keluarha merupakan contoh dari faktor eksternal pembentuk kepercayaan diri seseorang.

Penerapan teori belajar konstruktivis dapat digunakan pada pembentukan karakter kreatif dan percaya diri. Penggunaan konsep-konsep sebelumnya yang dimiliki seseorang dapat digunakan untuk membentuk sendiri konsepkonsep baru. Melalui pembelajaran yang bersifat konstruktif, peserta didik dituntut aktif membentuk kompetensi [22]. Pembelajaran berbasis konstruktivis mengindikasikan bahwa pembelajaran memerlukan lingkungan yang konstruktivitis yaitu lingkungan pembelajaran yang memerlukan konsep lingkungan fisik, sosial dan emosional, serta guru bertanggungjawab dalam mengkondisikan kegiatan pembelajaran [23].

Tahapan-tahapan yang ada pada pembelajaran konstruktif terdiri dari lima tahapan yaitu: orientasi, eksplorasi, interpretasi, re-kreasi dan implementasi [23]. Orientasi merupakan tahapan penyiapan peserta didik dalam pembelajaran. Selanjutnya tahapan eksplorasi dan interpretasi dari berbagai sumber untuk melakukan identifikasi, pendalaman dan penyimpulan informasi. Re-kreasi merupakan tahapan peserta didik membuat atau mengembangkan apa yang didapat dari tahap interpretasi dalam bentuk karya atau portofolio. Dalam tahap ini peserta didik diberi kebebasan dalam pengungkapan gagasan, ide atau karyanya sesuai dengan kompetensi yang diinginkan. Tahap terakhir yaitu implementasi, tahap ini merupakan pemanfaatan gagasan yang telah disusun dan juga sebagai wahana evaluasi bagi guru.

Project-Based Learning (PjBL) merupakan salah satu terapan dari pendekatan konstruktivis [24]. Tahapan-tahapan yang ada pada PjBL diantaranya adalah (1) identifikasi proyek; (2) penelitian dan perancangan (3) pengembangan; (4) pelaporan; dan (5) presentasi [25]. Pada tahapan awal, peserta didik mengidentifikasi dan meneliti permasalahan proyek. Selama proses tersebut, guru berperan sebagai fasilitator yang mendukung dan mengarahkan peserta didik menuju solusi yang tepat untuk proyek tersebut. Selanjutnya, peserta didik melaksanakan tahapan pengembangan, pelaporan dan presentasi proyek. Tahapan dalam PjBL dilakukan memerlukan kolaborasi tim, sehingga 
mendorong pembelajaran aktif dan menuntut siswa untuk mengembangkan soft skill peserta didik.

Berpijak dari berbagai paparan sebelumnya, dapat dinyatakan bahwa salah satu kendala guru selama melakukan pembelajaran dimasa darurat COVID-19 adalah rasa bosan. Hal tersebut akibat dari kegiatan belajar dari rumah yang kurang menuntut keaktifan peserta didik, kurangnya variasi penugasan yang diberikan guru dan keterbatasan sarana prasarana. Peserta didik dituntut untuk lebih meningkatkan kreatifitas dalam menyelesaikan tugas yang diberikan guru khususnya bidang kemampuan hidup (life skill) yang sarat dengan nilai-nilai penguatan pendidikan karakter. Peneliti berupaya menekan kebosanan sekaligus meningkatkan kreatifitas dan percaya diri peserta didik melalui penugasan video tutorial. Hal yang dilakukan pada mata pelajaran PKK pada penelitian ini merupakan penerapan PjBL dengan penugasan kepada peserta didik dengan pembuatan video tutorial terkait dengan kegiatan-kegiatan harian yang berhubungan dengan dunia otomotif. Penugasan tersebut didasarkan pada pembelajaran konstruktivis dimana peserta didik secara mandiri membangun pemahaman untuk menjadi lebih kreatif dan percaya diri terkait dengan kompetensi keahlian otomotif karena peserta didik dapat berimajinasi dan berfikir diluar rutinitas yang pernah dilakukannya selama mengerjakan tugas selama masa darurat COVID-19.

Artikel ini menyajikan pengalaman terbaik peneliti terkait penggunaan model PjBL dengan penugasan video tutorial pada mata pelajaran PKK selama kegiatan belajar dari rumah. Beberapa hal yang disajikan dalam artikel ini adalah: (1) gambaran langkah-langkah yang dilakukan dalam usaha meningkatkan kreatifitas dan kepercayaan diri peserta didik melalui penugasan pembuatan video tutorial terkait dengan kegiatan-kegiatan harian yang berhubungan dengan dunia otomotif; dampak yang ditimbulkan kepada peserta didik dari penugasan video tutorial terkait dengan kegiatan-kegiatan harian yang berhubungan dengan dunia otomotif; dan (3) faktor pendukung dan faktor penghambat dari penugasan video tutorial terkait dengan kegiatan-kegiatan harian yang berhubungan dengan dunia otomotif.

\section{METODE}

Kuasi eksperimen merupakan metode penelitian yang digunakan oleh peneliti pada penelitian ini. Shadish et al. menyatakan bahwa salah satu desain kuasi eksperimen adalah rancangan tanpa kelompok kontrol atau rancangan tanpa pengukuran praperlakuan [26]. Penelitian ini menggunakan satu kelas sebagai subjek eksperimen. Penelitian ini tidak melakukan pengukuran pra perlakuan. Perlakuan yang dimaksud adalah implementasi PjBL untuk penugasan video tutorial. Setelah model PjBL penugasan video tutorial dilakukan maka dilakukan pengukuran paska perlakuan. Evaluasi diakhir perlakuan dilakukan untuk menilai ketertarikan (tidak bosan) dan dua karakter, yaitu kreatifitas dan percaya diri. Pengukuran dilakukan menggunakan instrumen angket. Tabel 1 menunjukkan hubungan antara konstruktivis, $\mathrm{PjBL}$ dan penugasan video tutorial.

Tabel 1. Hubungan antara pendekatan konstruktivis, PjBL dan penugasan video tutorial

\begin{tabular}{|c|c|c|}
\hline $\begin{array}{l}\text { Pendekatan } \\
\text { konstruktivis }\end{array}$ & Tahapan pjbl & $\begin{array}{c}\text { Tahapan } \\
\text { penugasan } \\
\text { video tutorial }\end{array}$ \\
\hline Orientasi & & $\begin{array}{l}\text { Informasi dan } \\
\text { regulasi } \\
\text { (penyiapan } \\
\text { peserta didik) }\end{array}$ \\
\hline $\begin{array}{l}\text { Eksplorasi } \\
\text { Interpretasi }\end{array}$ & $\begin{array}{l}\text { Identifikasi, } \\
\text { penelitian dan } \\
\text { perancangan } \\
\text { proyek }\end{array}$ & Penggalian ide \\
\hline Re-kreasi & Pengembangan & $\begin{array}{l}\text { Pembuatan } \\
\text { video }\end{array}$ \\
\hline Implementasi & $\begin{array}{c}\text { Pelaporan dan } \\
\text { presentasi }\end{array}$ & $\begin{array}{l}\text { Pencarian } \\
\text { jejaring dan } \\
\text { pemberian } \\
\text { reward }\end{array}$ \\
\hline
\end{tabular}

Penugasan video tutorial pada mata pelajaran PKK dilaksanakan melalui empat 
tahapan yaitu: informasi dan regulasi tugas, penggalian ide, pembuatan video, pencarian jejaring dan pemberian reward. Berbagai tahapan tersebut tersaji pada Gambar 1. Tahapan orientasi pada pendekatan konstruktivis diimplementasikan dengan tahapan informasi dan regulasi. Tahapan tersebut digunakan untuk menyiapkan peserta didik. Pada tahap orientasi, guru memberikan informasi dan regulasi tentang penugasan video tutorial, informasi diberikan guru melalui kelas maya pada aplikasi google classroom. Pada kesempatan tersebut guru menginformasikan tentang tujuan pemberian tugas, tema video, durasi dan kapasitas video yang akan dibuat, waktu penugasan dan tautan (link) untuk pengiriman video.

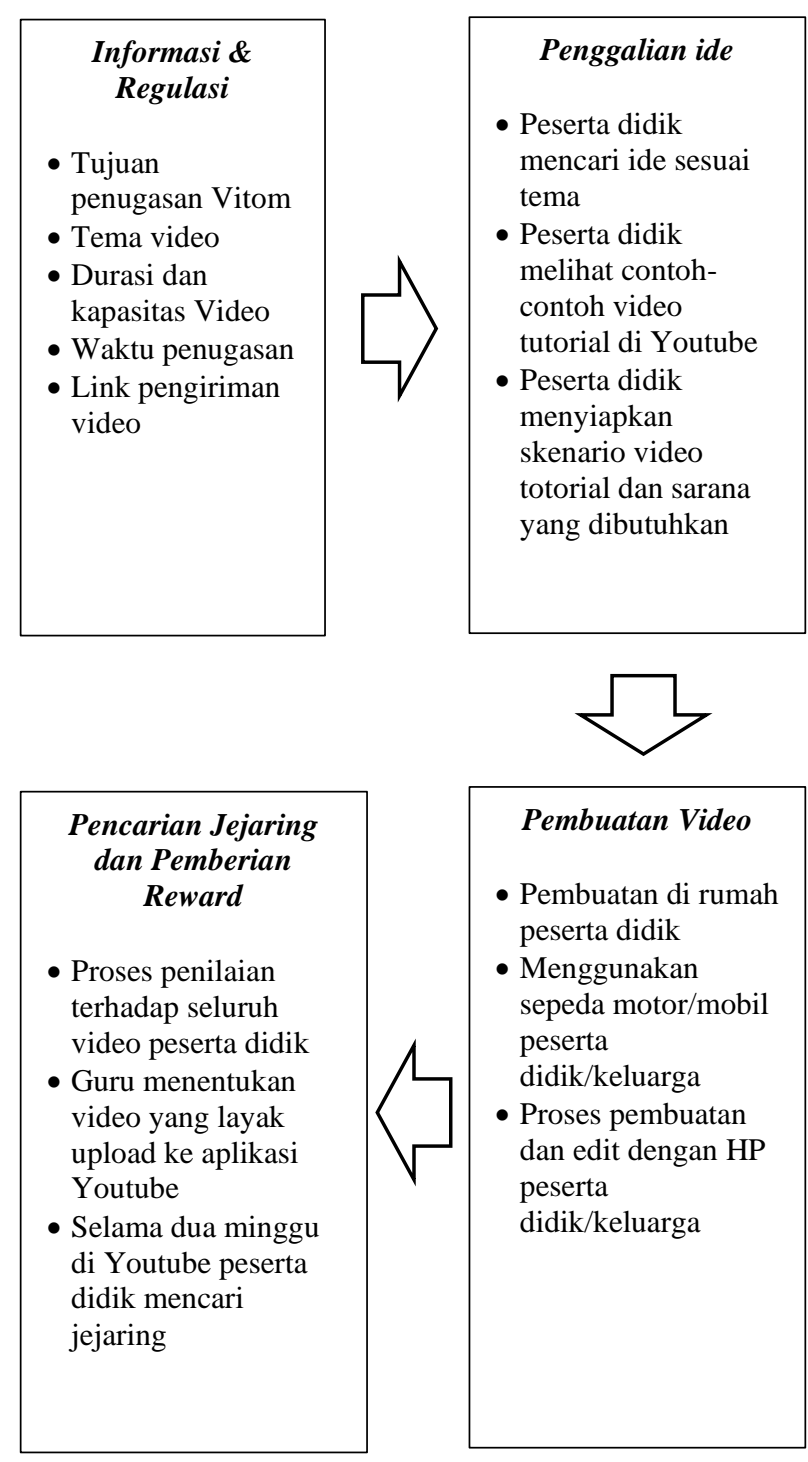

Gambar 1. Tahapan Pelaksanaan Kegiatan
Guru melakukan pendeskripsian penugasan video tutorial yang dimaksud dan identifikasi pekerjaan-pekerjaan bidang otomotif yang dapat diimplementasikan dalam penugasan tersebut. Penugasan video tutorial, berisi tentang tugas pembuatan video tutorial dalam bidang otomotif yang dilakukan oleh siswa dalam perawatan kendaraan yang dimiliki oleh siswa atau keluarganya. Bidang pekerjaan-pekerjaan yang bisa dibuat video tutorialnya meliputi pekerjaanpekerjaan dibidang otomotif yaitu: perawatan ringan komponen-komponen sepeda motor meliputi: perawatan baterai/aki, sistem suspensi (pegas, shock absorber, lengan ayun), tekanan ban sepeda motor, busi sepeda motor, perawatan radiator sepeda motor. Selain itu tema yang dapat diambil berkaitan dengan perawatan kebersihan komponen-komponen sepeda motor meliputi: perawatan kebersihan bodi sepeda motor, perawatan kebersihan blok mesin, perawatan kebersihan rantai sepeda motor, perawatan kebersihan ban sepeda motor dan perawatan kebersihan knalpot. Durasi dari video tutorial adalah 3 sampai dengan 5 menit. Peserta didik diharuskan menggunakan alat dan bahan yang ada di sekitar lingkungan peserta didik dengan biaya yang murah dan mudah untuk didapatkan. Kapasitas video ini dibatasi maksimal 100 Kilobyte $(\mathrm{Kb})$, pembatasan dimaksudkan agar mudah dalam proses pengiriman melalui aplikasi Google Form. Waktu pengerjaan tugas selama satu minggu, menggunakan link pada google form yang dibuat.

Tahapan penggalian ide terdiri dari tiga kegiatan yaitu: pencarian judul sesuai tema yang ditentukan, pencarian literasi untuk memperkaya ide video tutorial dan persiapan skenario serta sarana prasarana yang digunakan, tahapan ini termasuk dalam tahap eksplorasi dan interpretasi dalam tahapan pembelajaran konstruktivis. Tahapan pembuatan video merupakan tahap rekreasi. dimana dalam tahap ini peserta didik membuat video yang dilaksanakan dirumah masing-masing peserta didik, menggunakan kendaraan peserta didik atau keluarganya 
maksud dan tujuan hal tersebut agar peserta didik tetap berada dirumah sesuai dengan anjuran pemerintah pada masa pandemi COVID19. Video tutorial dibuat dengan menggunakan gawai/handphone peserta didik dengan menggunakan aplikasi pembuatan video. Pemeran utama video adalah peserta didik, namun proses pembuatanya dapat dibantu teman atau keluarga masing-masing. Proses editing dilakukan dengan menambahkan suara, kalimat yang mendukung proses dan musik/backsound agar video menjadi lebih menarik.

Tahapan pencarian jejaring dan pemberian reward merupakan tahap implementasi dalam pembelajaran konstruktivis, proses pencarian jejaring yang dimaksud disini adalah mencari penonton video tutorial pada aplikasi Youtube, dengan terlebih dahulu peserta didik mengupload ke aplikasi Youtube. Sebelum peserta didik mengupload video terlebih dulu guru menilai seluruh video peserta didik dan selanjutnya hanya peserta didik yang masuk dalam nominasi yang dapat mengupload video tutorialnya. Waktu yang digunakan nominator juara untuk mencari penonton pada aplikasi Youtube selama 7 hari, dalam rentang waktu tersebut peserta didik dapat mempromosikan video tutorialnya kepada teman, kenalan ataupun keluarganya agar menonton (view) menyukainya (like) dan mencari pelanggan (subscribe). Reward atau hadiah diberikan kepada juara setelah peserta didik selesai mencari jejaring selama kurun waktu 7 hari. Penilaian dilakukan guru dengan menggunakan instrumen penilaian video tutorial pada waktu penilaian, selain itu penilaian juga berdasarkan jumlah penonton (viewer), penyuka (like) dan pelanggan (subscribe) dari video tutorialnya. Maksud dari penilaian dengan menggunakan akun youtube agar penilaian bersifat netral karena dinilai orang lain dan membiasakan peserta didik menjalin jejaring kepada orang lain. Reward yang diberikan kepada peserta didik adalah kebutuhan bagi peserta didik selama melaksanakan pembelajaran jarak jauh yaitu kuota internet, faceshield dan masker.
Untuk mengevaluasi kegiatan maka diakhir penugasan dilakukan evaluasi dengan memberikan angket evaluasi yang diisi oleh seluruh peserta didik menggunakan google form. Angket evaluasi terdiri dari sembilan pertanyaan tertutup dan terbuka yang bertujuan untuk menggali ketertarikan peserta didik terkait dengan penugasan video tutorial, pertanyaan bersifat terbuka dengan tujuan menggali jawaban lebih terperinci. Kisi-kisi pertanyaan seperti terlihat pada Tabel 2. Komponen pertama dalam instrumen mengenai ketertarikan peserta didik yang digunakan untuk mengetahui apakah penugasan video tutorial mampu mengatasi permasalahan kegiatan belajar dari rumah yang diidentifikasi. Permasalahan yang dimaksud adalah rasa bosan peserta didik. Komponen berikutnya mengenai aspek penguatan karakter yang dapat dibangun dari penugasan video tutorial, yaitu kreatifitas dan percaya diri. Komponen terakhir adalah factor pendukung dan penghambat dalam penyelesaian penugasan video tutorial. Komponen tersebut digunakan untuk mendapatkan informasi terkait dukungan dan hambatan yang dialami peserta didik, sehingga dapat digunakan untuk perbaikan pada pembelajaran selanjutnya.

Tabel 2. Kisi-kisi pada kuesioner

\begin{tabular}{llc}
\hline \multicolumn{1}{c}{ Indikator } & $\begin{array}{c}\text { Nomor Butir } \\
\text { instrumen }\end{array}$ \\
\hline 1. & Ketertarikan penugasan & 1,2 \\
& video tutorial & \\
2. & Kreatifitas & $3,4,8$ \\
3. & Percaya diri & 5,6 \\
4. & Faktor pendukung/ & 7,9 \\
& penghambat & \\
\hline
\end{tabular}

Teknik analisa data kuesioner menggunakan analisis kuantitatif dengan prosentase (angket tertutup), sebelum dilakukan analisis kualitatif secara keseluruhan, sehingga hasil jawaban peserta didik diprosentase kemudian isian jawaban dari angket terbuka peserta didik dianalisis untuk menggali dan mempertajam hasil analisis sebelum ditarik kesimpulan. 


\section{HASIL DAN PEMBAHASAN}

Tahapan pelaksanaan kegiatan pembelajaran ini memerlukan waktu empat minggu. Pembelajaran diawali pada hari Senin tanggal 04 Mei 2020 sampai dengan hari Senin 9 Juni 2020. Subyek penelitian pada Kelas XI TKRA SMKN 1 Saptosari Gunungkidul sejumlah 36 peserta didik, selama proses penugasan pembuatan video tutorial sangat kooperatif terbukti dapat mengumpulkan tugas dengan tepat waktu dengan tema seperti yang telah ditentukan. Setelah dilakukan penilaian oleh guru menggunakan format yang sudah ditentukan, maka diperoleh sebanyak 13 peserta didik yang menjadi nominasi juara, untuk selanjutnya dilanjutkan dengan proses upload ke akun Youtube sebagai wahana untuk mencari jejaring dalam penilaian.

Setelah peserta didik mengumpulkan tugas selanjutnya peserta didik diberi angket untuk mengevaluasi penugasan yang diberikan. Gambar 2 menunjukkan prosentase ketertarikan peserta didik terhadap penugasan video tutorial. Berdasarkan data evaluasi tersebut sebanyak 30 peserta didik merasa tertarik pada penugasan video tutorial dengan perolehan prosentase sebesar $83.33 \%$ dari total peserta didik. Dilain pihak, terdapat enam peserta didik merasa tidak tertarik pada penugasan video tutorial dengan perolehan prosentase sebesar $16.67 \%$ dari total peserta didik. Peserta didik yang belum tertarik dengan penugasan video tutorial ini, dikarenakan banyaknya tahapan dalam proses pembuatan video mulai dari pembuatan skenario, pembuatan video dan editing video, masalah terbesar peserta didik belum menguasai dalam proses editing video oleh sebab itu dibutuhkan wahana dalam mengembangkan minat dan bakat peserta didik dalam pembuatan video melalui kegiatan ekstrakurikuler.

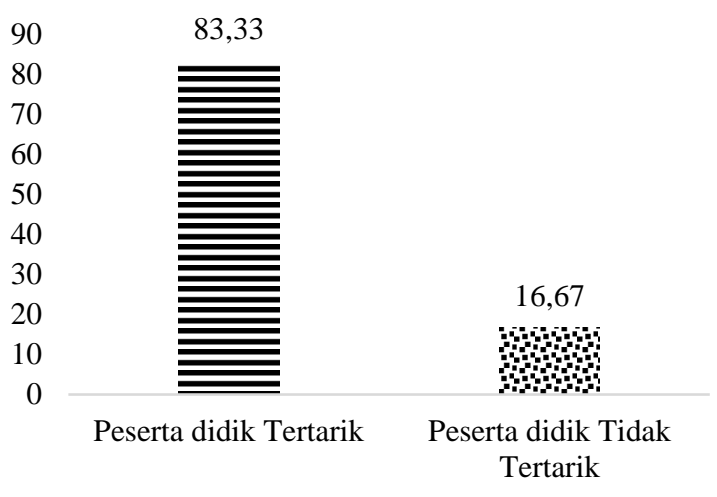

Gambar 2. Grafik Ketertarikan peserta didik terhadap penugasan video tutorial dengan model $\mathrm{PjBL}$

Hasil prosentase menunjukkan kecenderungan ketertarikan peserta didik pada penugasan video tutorial dengn model PjBL. Ketertarikan tersebut disebabkan oleh nuansa yang berbeda dari penugasan tugas selama pembelajaran jarak jauh atau terdapat perbedaan penugasan dari guru lain, sebanyak 26 peserta didik menilai terdapat perbedaan penugasan dibandingkan dengan guru lain dalam satu kelas. Ketertarikan yang lain dari peserta didik adalah senang belajar dengan menggunakan jenis video dan juga sudah terbiasa membuat video bertema tutorial yang sering di upload pada akun Youtube. PjBL mampu menghadirkan semangat dan ketertarikan belajar [27]. Ting menyatakan bahwa proyek video menghadirkan hal positif dan menghadirkan semangat. Ting menyatakan bahwa proyek video merupakan cara yang valid dan praktis untuk menghubungkan pembelajaran dengan konteks kehidupan nyata. Hal tersebut dikarenakan proyek video mampu melibatkan peserta didik dalam pengalaman yang autentik [28].

Ketidaktertarikan berada pada zona yang sama dengan kebosanan [29]. Berpijak dari hal tersebut, peserta didik yang bosan atau tidak tertarik (16.67\%) lebih sedikit dari peserta didik yang tertarik (83.33\%) dengan penugasan video tutorial. Dilain pihak, praktisi pendidikan perlu mengidentifikasi strategi untuk mengurangi kebosanan peserta didik dalam lingkungan akademik [30]. Pada penelitian ini yang dimaksud dengan lingkungan akademik adalah kegiatan belajar dari rumah dengan penugasan 
video tutorial dengan model PjBL. Temuan dari hasil penelitian pada Gambar 2 menunjukkan bahwa, penugasan video tutorial cenderung dapat menggugah ketertarikan belajar peserta didik. Dengan demikian, strategi penugasan video tutorial dengan model $\mathrm{PjBL}$ dinilai berhasil untuk mengurangi kebosanan peserta didik pada kegiatan belajar dari rumah.

Pada komponen kreatifitas, indikator kreatifitas dipilih oleh 29 peserta didik, yaitu memiliki prosentase sebesar $80.56 \%$ dari jumlah peserta didik. Indikator sama dengan orang lain dipilih oleh dua peserta didik dengan prosentase sebesar 5.56\%. Terakhir, terdapat lima peserta didik pada indikator ketiga yaitu tampil seadanya atau dengan perolehan prosentase sebesar 13,89\%. Gambar 3 menunjukkan kreatifitas melalui pembelajaran $\mathrm{PjBL}$ dengan penugasan video tutorial. Peserta didik yang kreatif mampu mengeksplorasi atau melihat berbagai hal dari banyak perspektif dengan cara yang berbeda daripada umumnya [31], [32]. Temuan yang menunjukkan bahwa indikator ingin tampil beda $(80.56 \%)$ memiliki prosentase paling besar diantara indikator lainnya (sama dengan orang lain sebesar $5.56 \%$ dan tampil seadanya sebesar $13,89 \%$ ) menunjukkan bahwa pembelajaran PjBL melalui penugasan video tutorial mampu menguatkan karakter kreatifitas.

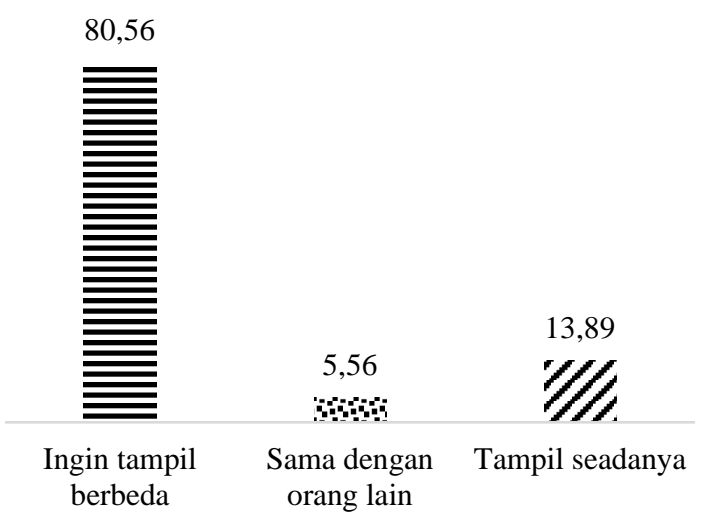

Gambar 3. Grafik Kreatifitas melalui pembelajaran $\mathrm{PjBL}$ dengan penugasan video tutorial
Hasil temuan riset memiliki keselarasan dengan hasil penelitian Yamin et al. bahwa PjBL mampu meningkatkan kreatifitas [33]. Tambahan hasil temuan juga didukung oleh Sumardi et al. yaitu proyek video digital mampu meningkatkan kreatifitas [34]. Kreatifitas merupakan salah satu aspek yang dibutuhkan pada pembelajaran abad 21 [35]. Hal tersebut mengandung pengertian bahwa penguatan karakter kreatifitas melalui model PjBL dengan penugasan video tutorial merupakan langkah strategis untuk pembelajar abad 21.

Gambar 4 menunjukkan terdapat dua indikator komponen percaya diri, yaitu berani dan tidak berani tampil di muka umum. Terdapat 33 peserta didik atau $91.67 \%$ peserta didik merasa bertambah tingkat kepercayaan dirinya untuk berbicara dimuka umum setelah pembuatan video tutorial. Dengan prosentase yang jauh lebih sedikit, terdapat 3 peserta didik atau $8,33 \%$ peserta didik merasa tidak berani atau malu jika tampil dimuka umum. Martin menyatakan bahwa hasil dari pemodelan persamaan struktural menunjukkan bahwa keberanian dan kepercayaan diri tidak berbeda secara signifikan pada beberapa ukuran akademis (termasuk kinerja) [36]. Dengan kata lain, keberanian mampu merepresentasikan kepercayaan diri. PjBL mampu meningkatkan kepercayaan diri pada keterampilan berbicara [37]. Peningkatan keterampilan tersebut juga dapat ditingkatkan melalui proyek video [38]. Berpijak dari kedua hasil riset tersebut, apabila dikaitkan dengan hasil temuan riset ini, maka dapat dinyatakan bahwa model PjBL dengan penugasan video tutorial mampu memperkuat rasa percaya diri peserta didik. Peserta didik memiliki rasa percaya diri dikarenakan penguasaan materi terkait video tutorial yang telah dikembangkan. Peserta didik terlibat secara aktif. 


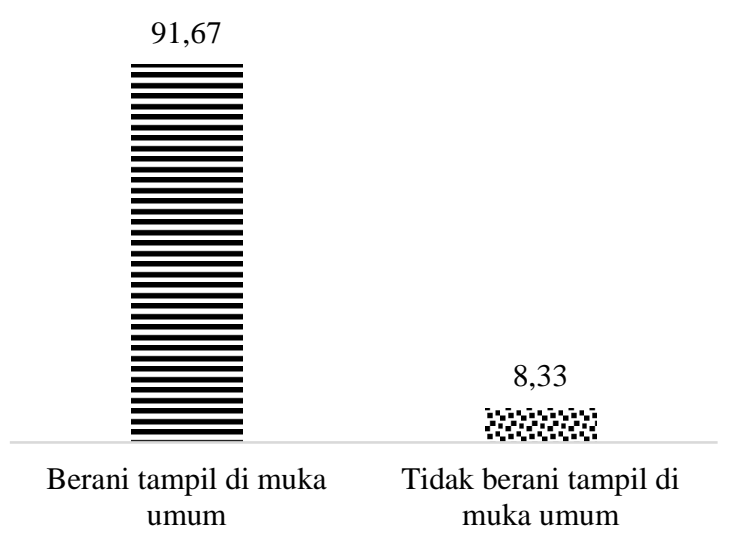

Gambar 4. Grafik Percaya diri melalui pembelajaran PjBL dengan penugasan video tutorial

Dari pemaparan ketiga hasil komponen pada instrumen angket dapat disimpulkan bahwa, peserta didik memiliki kecenderungan tertarik (tidak bosan) serta mendapatkan penguatan karakter kreatifitas dan percaya diri melalui model PjBL dengan penugasan video tutorial. Isian dari komponen faktor pendukung dan penghambat mampu menggali beberapa temuan. Faktor pendukung dalam keberhasilan penerapan $\mathrm{PjBL}$ dengan penugasan video tutorial adalah semangat dan sifat kooperatif peserta didik. Hal tersebut berimbas adanya tindak lanjut yang akan dilakukan peserta didik setelah penugasan selesai. Peserta didik memiliki inisiatif akan mengembangkan video tutorial yang sudah dibuat menjadi lebih baik.

Secara umum, beberapa penghambat pada penerapan $\mathrm{PjBL}$ dengan penugasan video tutorial adalah sinyal yang kurang baik, kualitas video dan kuota internet yang terbatas. Lemahnya sinyal disekitar rumah dan kuota yang terbatas dikarenakan faktor tempat atau lokasi peserta didik yang berada jauh dari jaringan internet. Masalah yang kedua adalah kualitas video yang kurang baik, yang disebabkan oleh kurangnya keterampilan peserta didik dalam proses mengedit video, selanjutnya tentang masalah kualitas gambar diakibatkan video diambil dari handphone peserta didik yang berbeda-beda spesifikasinya, tidak menggunakan kamera yang beresolusi tinggi serta faktor pembatasan kapasitas video $100 \mathrm{~Kb}$.
Masalah yang ketiga adalah kuota internat yang terbatas dikarenakan faktor ekonomi orangtua.

Peneliti melakukan evaluasi dari hasil video tutorial para peserta didik. Beberapa hal yang dapat dilakukan untuk penugasan video tutorial pada kegiatan belajar selanjutnya adalah: (1) penggunaan kamera dengan spesifikasi/resolusi yang layak untuk pembuatan video atau tidak menggunakan kamera pada telepon genggam, hal tersebut dapat ditindaklanjuti oleh sekolah dalam pengadaan kebutuhan alat dan bahan praktik sekolah; dan (2) pemberian materi pra penugasan video turoial yang terdiri atas pemberian materi seputar pembuatan skenario, pengambilan video dan editing video. Penelitian ke depan diharapkan mampu menggali informasi terkait capaian pembelajaran yang belum diungkap secara dalam pada artikel ini.

\section{SIMPULAN}

Berdasarkan pengalaman terbaik yang penulis lakukan tentang penggunaan model PjBL dengan penugasan video tutorial menunjukkan bahwa: (1) tahapan penugasan pembuatan video tutorial pada mata pelajaran PKK terdiri atas: (a) informasi dan regulasi tugas; (b) penggalian ide; (c) pembuatan video; serta (d) pencarian jejaring dan pemberian reward; (2) terdapat kecenderungan peserta didik tertarik (tidak bosan) dan mampu menguatkan karakter kreatif dan percaya diri; (3) faktor pendukung dalam penugasan video tutorial ini adalah semangat dan sifat kooperatif peserta didik terbukti tugas dikumpulkan sesuai tema dan tepat waktu serta peserta didik ingin mengembangkan kemampuan membuat video yang lebih baik; dan (4) faktor penghambat yang dirasakan peserta didik dalam penugasan ini adalah sinyal yang kurang baik disekitar rumah, kualitas video terutama pada kemampuan peserta didik dalam proses editing video tutorial dan kuota internet yang terbatas. Ketertarikan peserta didik terjadi dikarenakan terdapat nuansa yang berbeda dengan penugasan yang dilakukan guru lain. Kreatifitas telah terbentuk dari penugasan ini terlihat dari indikator kreatifitas yaitu ingin tampil berbeda dengan teman yang 
lain dan bervariasinya judul video yang dibuat peserta didik. Rasa percaya diri timbul sebagai hasil dari keterlibatan aktif peserta didik dalam menghasilkan video tutorial. Beberapa rekomendasi untuk penugasan video tutorial selanjutnya adalah pemberian fasilitas untuk pembuatan video dan pemberian materi seputar pembuatan skenario, pengambilan video dan editing video. Penelitian ke depan diharapkan mampu menilai capaian pembelajaran secara komprehensif, termasuk hasil belajar.

\section{DAFTAR PUSTAKA}

[1] A. Susilo et al., "Coronavirus Disease 2019: Tinjauan Literatur Terkini," J. Penyakit Dalam Indones., vol. 7, no. 1, p. 45, Apr. 2020.

[2] N. Mona, "Konsep isolasi dalam jaringan sosial untuk meminimalisasi efek contagious (kasus penyebaran virus corona di Indonesia)," J. Sos. Hum. Terap., vol. 2, no. 2, pp. 117-124, Jan. 2020.

[3] M. P. dan K. R. Indonesia, Surat Edaran Menteri Pendidikan dan Kebudayaan Nomor 3 Tahun 2020 tentang Pencegahan dan Penanganan Coronavirus Disease (COVID19) pada Satuan Pendidikan. Jakarta, Indonesia, 2020.

[4] R. H. Syah, "Dampak Covid-19 pada Pendidikan di Indonesia: Sekolah, Keterampilan, dan Proses Pembelajaran," SALAM J. Sos. dan Budaya Syar-i, vol. 7, no. 5, pp. 395-402, Apr. 2020.

[5] L. G. M. Z. Atsani, "Transformasi media pembelajaran pada masa pandemi COVID19," Al-Hikmah J. Stud. Islam, vol. 1, no. 1, pp. 82-93, 2020.

[6] M. P. dan K. R. Indonesia, Surat edaran mendikbud no 4 tahun 2020 tentang pelaksanaan kebijakan pendidikan dalam masa darurat penyebaran corona virus disease (COVID- 19). Jakarta, Indonesia, 2020.

[7] M. P. dan K. R. Indonesia, Surat Edaran Menteri Pendidikan dan Kebudayaan Nomor 15 Tahun 2020 tentang Pedoman penyelenggaraan belajar dari rumah dalam masa darurat penyebaran corona yirus disease (COVID-19). Jakarta, Indonesia, 2020.
[8] R. Pawicara and M. Conilie, "Analisis Pembelajaran Daring terhadap Kejenuhan Belajar Mahasiswa Tadris Biologi IAIN Jember di Tengah Pandemi Covid-19," ALVEOLI J. Pendidik. Biol., vol. 1, no. 1, pp. 29-38, 2020.

[9] D. Ramanta and F. D. Widayanti, "Pembelajaran Daring di Sekolah Menengah Kejuruan Putra Indonesia Malang pada Masa Pandemi COVID-19," Pros. Semin. Bimbing. dan Konseling, no. 5, 2020.

[10] Zainal Abidin; Adeng Hudaya \& Dinda Anjani, "Efektifitas Pembelajaran Jarak Jauh Pada Masa Pandemi Covid 19," Res. Dev. J. Educ., 2020.

[11] S. Utami and P. Utami, "Penggunaan Whatsapp Group dan Google Classroom untuk Meningkatkan Partisipasi dan Hasil Belajar Peserta Didik Teknik Audio Video," Elinvo (Electronics, Informatics, Vocat. Educ., vol. 5, no. 1, pp. 75-88, Sep. 2020.

[12] . Rita E. I., et.al, "Buku Pegangan Kuliah Perkembangan Peserta Didik," Yogyakarta, 2007.

[13] Ayunda Pininta Kasih, "Covid 19, ini Sederet Perubahan Kebijakan Pendidikan di Indonesia.," Kompas.com, Jakarta, p. 1, 2020.

[14] S. Siswati, "Pengembangan soft skills dalam kurikulum untuk menghadapi revolusi industri 4.0," Edukasi J. Pendidik., vol. 17, no. 2, pp. 264-273, Dec. 2019.

[15] E. He, A. Anak, G. S. De, and R. He, "Hubungan Self-Confidence dan Kemampuan Berpikir Kreatif Matematik Peserta Didik yang Diajar Menggunakan Model Electing Activities (MEAs)," J. Authentic Res. Math. Educ., vol. 1, no. 1, pp. 1-9, 2019.

[16] P. Sutowo, "Peningkatan Kreatifitas Siswa Kelas XI Kompetensi Keahlian Teknik elektronika Industri SMKN 2 Pengasih dalam Memahami Konsep Sensor dan Aktuator dengan Metode Mind Mapping," p. 1, 2015.

[17] Y. Nashr, Anakku Juara, Mencetak Anak Berkarakter, Positif, Unggul, Kreatif dan Berakhlak Mulia. Solo: Tinta Medina, 2014.

[18] T. Hakim., Mengatasi Rasa Tidak Percaya Diri. Jakarta: Puspa Swara., 2005.

[19] P. Sarastika., Stop Minder \& Grogi: Saatnya Tampil Beda dan Percaya Diri, 1 st ed. Yogyakarta: Araska, 2014.

[20] W. N. E. Saputra, "Meningkatkan Percaya Diri Siswa melalui Teknik Cognitive 
Defusion," J. Kaji. Pendidik. dan Konseling., vol. 3, pp. 14-21, 2018.

[21] C. B. Yudha, "Peningkatan Kepercayaan Diri dan Proses Belajar Matematika Menggunakan Pendekatan Realistik Pada Siswa Sekolah Dasar," J. Prima Edukasia, vol. 2, pp. 42-56, 2014.

[22] P. Utami and P. Pardjono, "Perbedaan Jigsaw II dan GI terhadap pemahaman konsep dan pemecahan masalah masalah pada kompetensi mendiagnosis permasalahan pengoperasian PC dan Peripheral ditinjau dari motivasi belajar," J. Pendidik. Vokasi, vol. 3, no. 2, Jun. 2013.

[23] H. J. Fraser, B.J. and Walberg, Improving Science Education. Chicago: The National Society for The Study of Education, 1995.

[24] M. Baghoussi and I. Zoubida El Ouchdi, "The Implementation of the Project-Based Learning Approach in the Algerian EFL Context: Curriculum Designers' Expectations and Teachers' Obstacles," Arab World English J., vol. 10, no. 1, pp. 271-282, Mar. 2019.

[25] A. L. Felipe, E. Amouroux, T. Pham, and A. Stojcevski, "Vietnamese Students Awareness towards a Project Based Learning Environment," in 8th International Symposium on Project Approaches in Engineering Education/14th Active Learning in Engineering Education Workshop, 2016, pp. 320-324.

[26] T. D. Hastjarjo, "Rancangan EksperimenKuasi," Bul. Psikol., vol. 27, no. 2, pp. 187203, Dec. 2019.

[27] Retnaningsih $\square$, S. Ridlo, and N. W.H, "The Effectiveness of Project-Based Learning Model and Assessment of Learning Outcomes Against Portfolio," J. Innov. Sci. Educ., vol. 18, no. 2, pp. 153-162, 2019.

[28] N. C. Ting, "Classroom Video Project: An Investigation on Students Perception," Procedia - Soc. Behav. Sci., vol. 90, pp. 441448, Oct. 2013.

[29] R. V. Small, B. J. Dodge, and X. Jiang, "Dimensions of Interest and Boredom in Instructional Situations," 1996.

[30] V. M. C. Tze, L. M. Daniels, and R. M. Klassen, "Evaluating the Relationship Between Boredom and Academic Outcomes: A Meta-Analysis," Educ. Psychol. Rev., vol. 28, no. 1, pp. 119-144, Mar. 2016.

[31] G. Kelemen, "Creativity, performance and emotional balance," Plus Educ., vol. 18, no. 2, pp. 38-46, 2017.

[32] M. O'Sullivan, "Chapter 4: Innovation and creativity," in Developing the Cambridge learner attributes, Cambridge Assessment International Education, 2011, pp. 1-122.

[33] Y. Yamin, A. Permanasari, S. Redjeki, and W. Sopandi, "Implementing project-based learning to enhance creative thinking skills on water pollution topic," JPBI (Jurnal Pendidik. Biol. Indones., vol. 6, no. 2, pp. 225-232, Jul. 2020.

[34] S. Sumardi, R. 'Adzima, and A. N. Wijaya, "Digital Video Project: An Authentic Assessment to Assess Students' Speaking Skills," Indones. J. EFL Linguist., vol. 5, no. 1, pp. 57-72, May 2020.

[35] P. Utami, G. P. Cikarge, M. E. Ismail, and S. Hashim, "Teaching Aids in Digital Electronics Practice through Integrating 21st Century Learning Skills using a conceptual approach," in Journal of Physics: Conf. Series, pp. 1-9.

[36] A. J. Martin, "Courage in the classroom: Exploring a new framework predicting academic performance and engagement.," Sch. Psychol. Q., vol. 26, no. 2, pp. 145-160, Jun. 2011.

[37] A. Marisah and R. H. Robiasih, "The implementation of project-based learning to improve vocational students' speaking skills," J. English Lang. Lang. Teach., vol. 1, no. 2, pp. 27-32, 2017.

[38] C. Yükselir and Ş. Kömür, "Using online videos to improve speaking abilities of EFL learners," Eur. J. Educ. Stud., vol. 3, no. 5, pp. 255-266, 2017. 